\title{
Long-term studies find benefits, challenges in alternative rice straw management
}

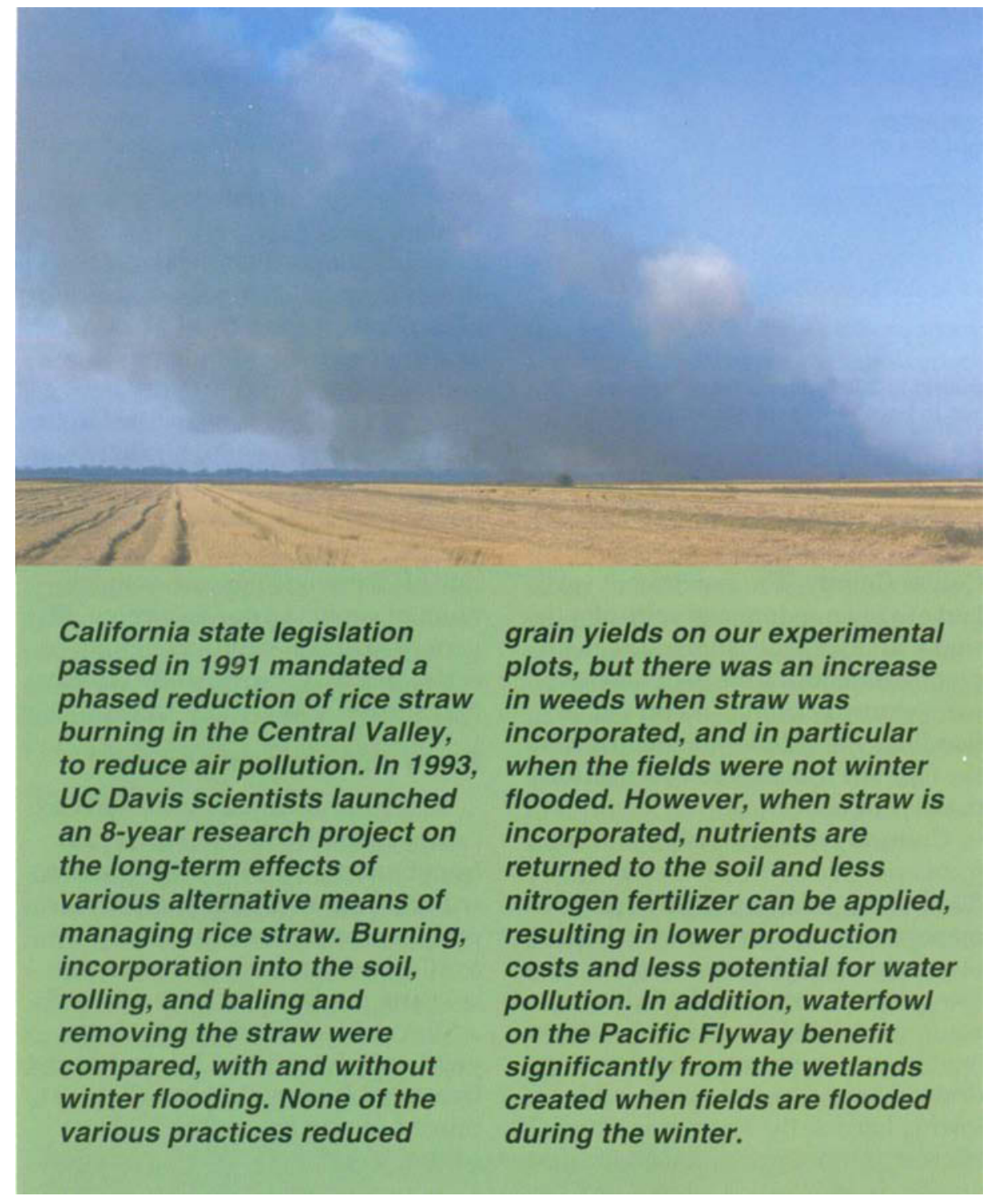

$\mathrm{R}$ ice straw management in California's Central Valley has undergone profound changes over the past decade. Historically, rice growers routinely burned their field to dispose of rice straw for sanitation and seedbed preparation purposes. In 1989, when 400,000 acres of rice were grown in California, $95 \%$ of the resulting debris was burned in the field, creating air pollution in the Central Valley and statewide.

\author{
Jeffrey A. Bird Alison J. Eagle \\ William R. Horwath \\ Mike W. Hair Eric E. Zilbert \\ Chris van Kessel
}

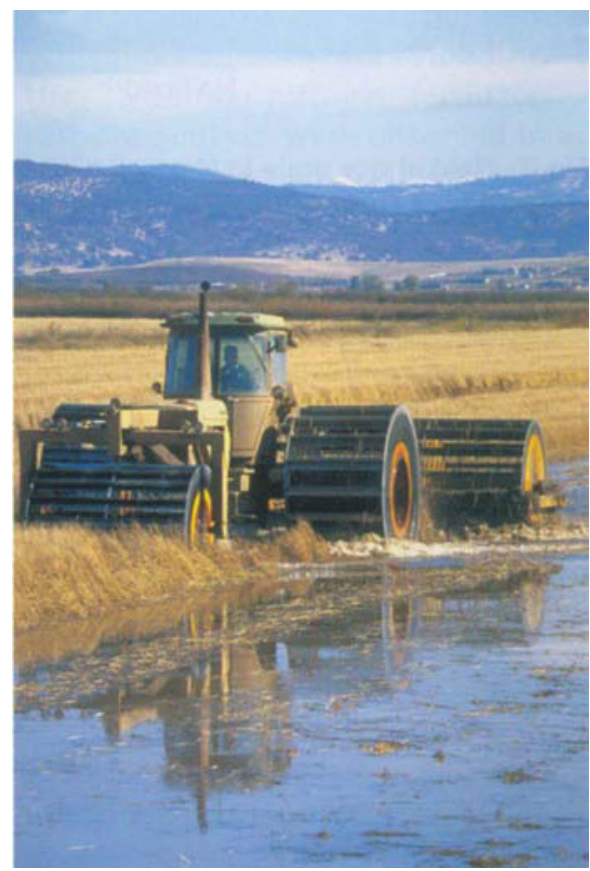

The burning of rice straw, top left, was the norm until 1991, when a state law was passed to phase out the practice in order to prevent air pollution. Growers have turned to alternative practices such as winter flooding of fields, above, to reduce weed and disease pressure. Winter flooding has also been a boon for birds on the Pacific Flyway.

reduction in burning is likely. The intent of the phase-down was to allow growers to make a gradual transition and allow some burning while alternative uses for straw were developed. Unfortunately, the market for rice straw has failed to grow as anticipated. Less than $3 \%$ of straw that is not burned is used off site (CRARB/ CDFA 2000), resulting in a dramatic increase in the incorporation of rice straw. 


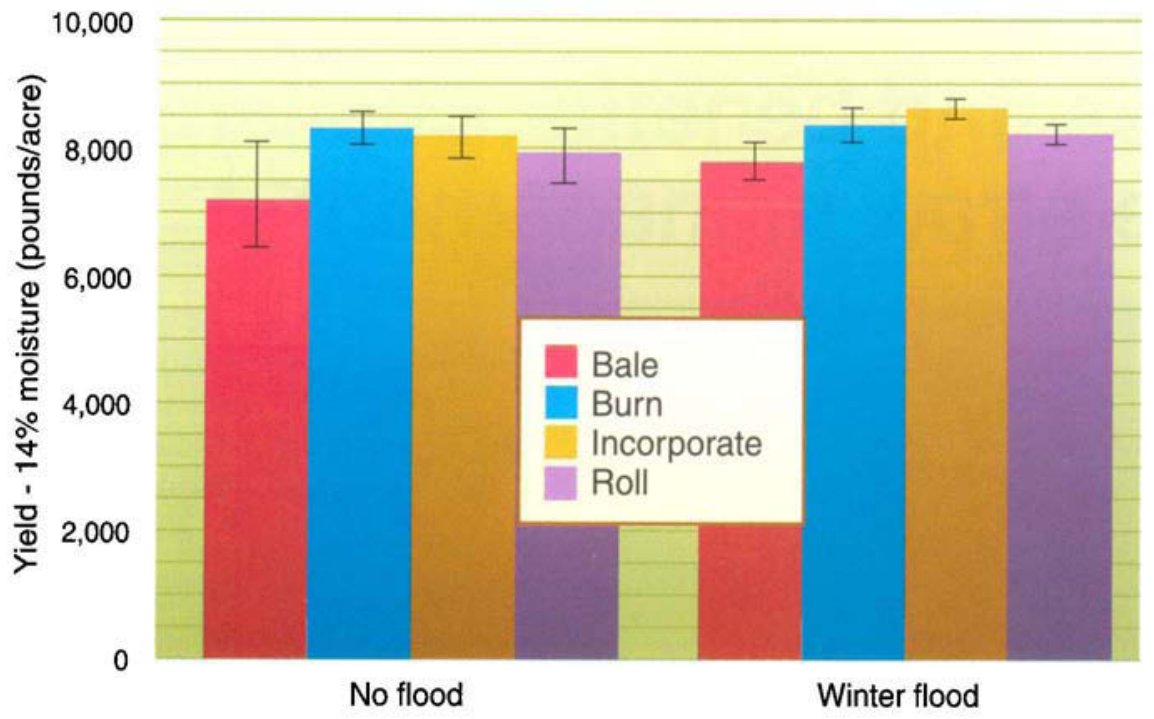

Fig. 1. Yield of rice grain in Maxwell (Colusa County) in 2000, after seven seasons of alternative straw management practices. Lines in bars represent standard error.
In 1993, UC Davis scientists launched an 8-year research project on the long-term effects of various alternative rice straw management practices. With funding from the California Energy Commission, Ducks Unlimited and the California Rice Research Board, several alternatives to burning were examined for their effects on rice yield, soil fertility, insect pests, diseases and weeds. Four straw management practices were examined:

burning, incorporation, rolling, and baling and removing the straw. Each of these straw treatments was compared with and without winter flooding, resulting in the evaluation of eight different straw management practices. In this review, we summarize the key findings of several related studies.

\section{The research effort}

The primary purpose of the project was to examine the impact of longterm straw incorporation and winter flooding on nutrient cycling and rice production. An experimental site was established in fall 1993, at Maxwell in Colusa County. The experiment was laid out in a randomized split-plot design with four replications. The main plot treatments for the experiment were winter flooding and no winter flooding. The subplot treatments were the four straw management practices mentioned above.

Cultural practices typical for California rice production were used for flood water, tillage, pest and fertilizer management. Field plots were large ( 2 acres per subplot treatment) to allow the use of commercial field-scale equipment. Fields were flooded during the growing season and then drained before harvest. Each fall following harvest the straw was either (1) burned, (2) chopped and then incorporated using a chisel plow or disc, (3) rolled with a heavy roller to crush the straw into the soil surface, or (4) wind-

\begin{tabular}{ll}
\multicolumn{10}{c}{ TABLE 1. Nutrient content of rice straw (pounds/acre) after $\mathbf{6}$ years of treatment } \\
(assumes $\mathbf{1 0 , 0 0 0}$ pounds straw/acre)
\end{tabular}

rowed, baled and removed from the field.

Fields were winter flooded 4 to 6 inches deep following the completion of the straw management practices and drained in early spring to allow sufficient time for soils to dry before spring tillage. Fields were tilled in the spring and nitrogen $(\mathrm{N})$ fertilizer was applied at an average rate of $\mathbf{1 5 0}$ pounds per acre as aqua ammonia, and phosphorous $(\mathrm{P})$ at an average rate of 20 pounds per acre as ammonium phosphate prior to seeding. Rice variety M202 (medium-size grain, early variety, approximately 140 days to maturity) was aerially seeded.

\section{Straw management and yield}

Rice growers in California have expressed concern that the conversion from burning to incorporating straw will increase weed and plant disease problems and possibly immobilize available soil nitrogen, thereby increasing the need for pesticide and additional fertilizer inputs. Grain yield was determined for each straw treatment from yield plots that ranged in size from 10 to 1,000 square feet (fig. 1). When averaged across years, grain yield was not significantly different among all straw treatments. Winter flooding had no significant effect on grain yield.

When straw is baled and removed, nutrients are exported from the field. Rice straw was collected when the straw treatments had been in place for 6 years. Straw was analyzed for elemental composition in the UC Division of Agriculture and Natural Resources (ANR) Analytical Laboratory at UC Davis using standard procedures (table 1). The nitrogen in rice 

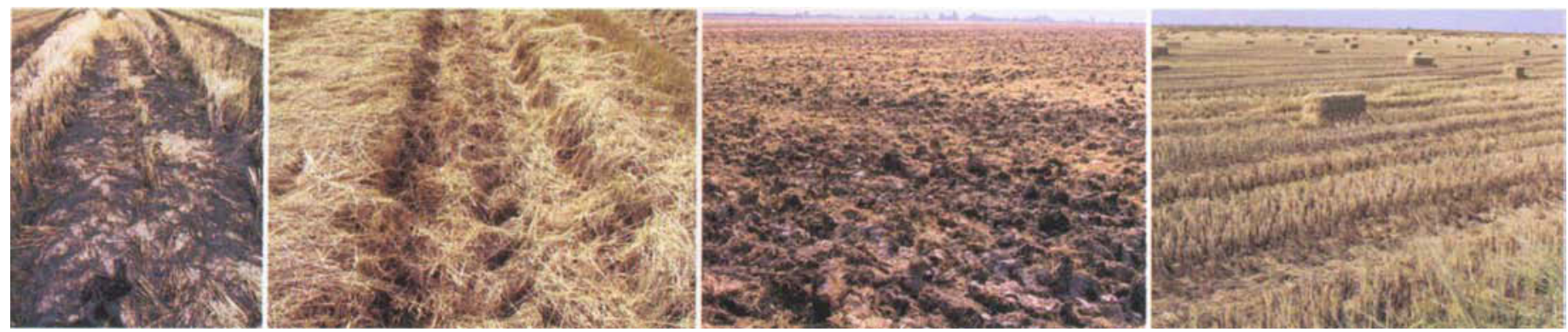

In an 8-year study, a variety of alternatives to rice straw burning were evaluated for impacts on yield, soil fertility, insect pests, disease and weeds. From left to right: burned, cut, stubble-disked and baled rice straw.

straw ranges between 61 and 70 pounds per acre, and the amount of potassium $(\mathrm{K})$ can be as much as 80 pounds per acre. Phosphorus levels in the straw ranged from 13 to 14 pounds per acre. It should be pointed out that approximately $50 \%$ to $60 \%$ of the straw will actually be baled and removed, and therefore the absolute amounts of nutrients removed will be less than reported in table 1.

Although nitrogen and phosphorus fertilizers were applied, potassium was not. Since most of the potassium taken up by the rice plant is in the straw and roots, the bale and remove treatment would result in substantial potassium losses from the system.

\section{Soil fertility}

Several studies were conducted to determine the effects of straw management practices on soil fertility. Zeronitrogen microplots were established within each main plot treatment. The microplots received no nitrogen fertilizer. Phosphorus was added to the zero-nitrogen plots at rates equivalent to those applied to the main plots.
After 3 years, rice grain yield in the zero-nitrogen microplots was significantly affected by straw treatment (Eagle et al. 2000, 2001). From 1996 through 1999, treatments where straw was rolled or incorporated showed higher grain yields for every year than where the straw was burned or baled. Overall, winter flooding had no impact on grain yields with or without nitrogen fertilizer. This data suggests that rolling or incorporation of rice straw had increased the soil nitrogen supply of the fields after 3 years of straw retention. This appears to contradict the finding of no improvement in yields with standard rates of nitrogen fertilizer with straw incorporation. This is due to the fact that the amount of nitrogen fertilizer applied exceeds the amount needed for optimum yields.

To determine the amount of nitrogen fertilizer that can be reduced with annual straw incorporation, a nitrogen fertilizer response study was initiated in 1998 and carried out for three growing seasons. Progressively increasing levels of nitrogen fertilizer were ap-

\begin{tabular}{|c|c|c|c|c|c|}
\hline \multirow[b]{2}{*}{ Treatment } & \multicolumn{5}{|c|}{ Soil N pools } \\
\hline & $\underset{\mathrm{N}}{\text { Inorganic }}$ & $\begin{array}{l}\text { Microbial } \\
\text { biomass }\end{array}$ & $\begin{array}{l}\text { Light } \\
\text { fraction }\end{array}$ & $\begin{array}{l}\text { Mobile } \\
\text { humic }\end{array}$ & $\begin{array}{l}\text { Total } \\
\text { soil N }\end{array}$ \\
\hline Burn/flood & 16.2 & 62.2 & 40.2 & 493 & 1930 \\
\hline Burn/no flood & 11.5 & 66.3 & 43.8 & 455 & 1974 \\
\hline Incorporate/flood & 16.0 & 79.8 & 47.3 & 536 & 1927 \\
\hline Incorporate/no flood & 13.7 & 86.6 & 52.7 & 522 & 1940 \\
\hline \multicolumn{6}{|l|}{$P$ values } \\
\hline Straw & 0.039 & 0.003 & 0.095 & 0.109 & NSt \\
\hline Flood & 0.055 & NS & NS & NS & NS \\
\hline $\mathrm{S} \times \mathrm{F}$ & NS & NS & NS & NS & NS \\
\hline
\end{tabular}

plied on subplots located within the subplot treatments where rice straw was either burned or incorporated, with and without winter flooding (fig. 2). Similar nitrogen-fertilizer response curves were observed in all three years. As the level of nitrogen fertilizer applied increased, grain yields increased when straw was burned or incorporated. However, grain yields when straw was incorporated were higher than when straw was burned and received nitrogen fertilizer up to a rate of 120 pounds nitrogen per acre. These rate trials indicate that nitrogen fertilizer application can be decreased when straw is incorporated, because no yield response was further observed when more than 100 pounds nitrogen per acre was applied.

Based on all the results of the nitrogen application-rate study, we recommend that nitrogen rates can be decreased by at least 25 pounds per acre after 5 years of straw incorporation (Eagle et al. 2000, 2001).

\section{Cycling of nitrogen and carbon}

To further investigate the increased soil-nitrogen availability due to straw incorporation, new experiments were started in 1997 using labeled (heavy) nitrogen $\left({ }^{15} \mathrm{~N}\right)$. These experiments sought to answer three primary questions:

1. How much of the nitrogen taken up by the crop is from fertilizer and how much is from the soil?

2. Does the efficiency of added nitrogen fertilizer differ with straw incorporation or burning?

3. Does annual straw incorporation build up soil nitrogen and carbon $(\mathrm{C})$ ?

The ${ }^{15} \mathrm{~N}$ experiment confirmed the finding of increased soil nitrogen up- 
take through incorporation. The cumulative effects of straw incorporation over the years led to greater net nitrogen mineralization, an increase in microbial biomass nitrogen and greater recovery of ${ }^{15} \mathrm{~N}$ in the soil 1 year after application (Bird et al. 2001, in press)(table 2).

Carbon and nitrogen are retained in soil organic matter when straw is incorporated (fig. 3). The carbon is fixed by the plant via photosynthesis; the nitrogen is taken up by the crop from soil mineral nitrogen. This pool of available soil nitrogen consists of native soil nitrogen that has been mineralized by microbes or introduced to the system through the application of nitrogen fertilizer. When the crop residue is incorporated into the soil, some of the carbon and nitrogen move into what is known as the labile soil organic matter pool, which consists of partially broken-down residues and soil microbes. Some of the carbon and nitrogen is sequestered in the more stabilized fractions.

The study showed that a consistently larger soil microbial biomass nitrogen pool was observed when straw was incorporated than when burned

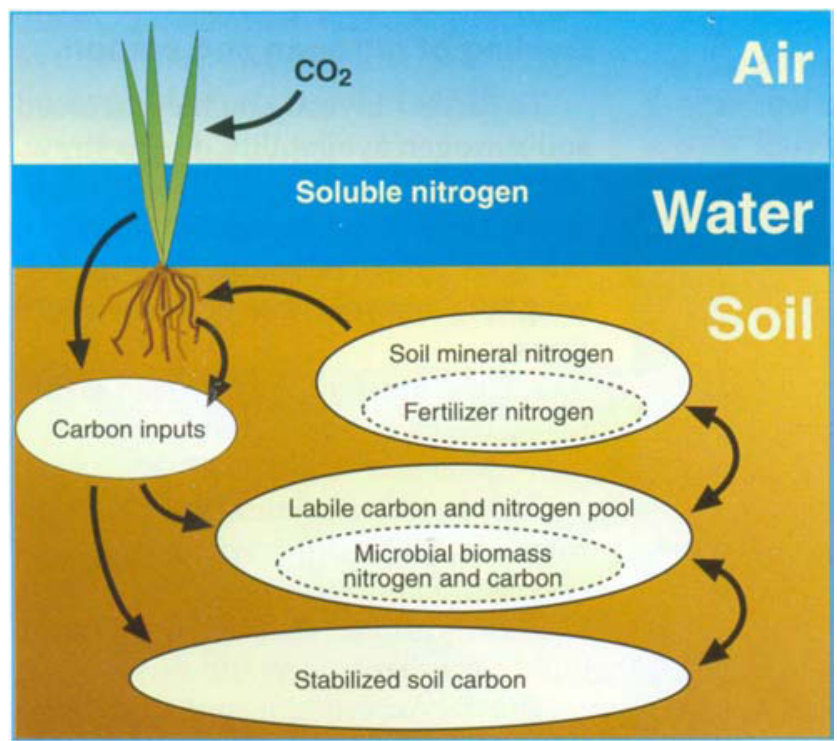

Fig. 3. Carbon-nitrogen interactions in rice.

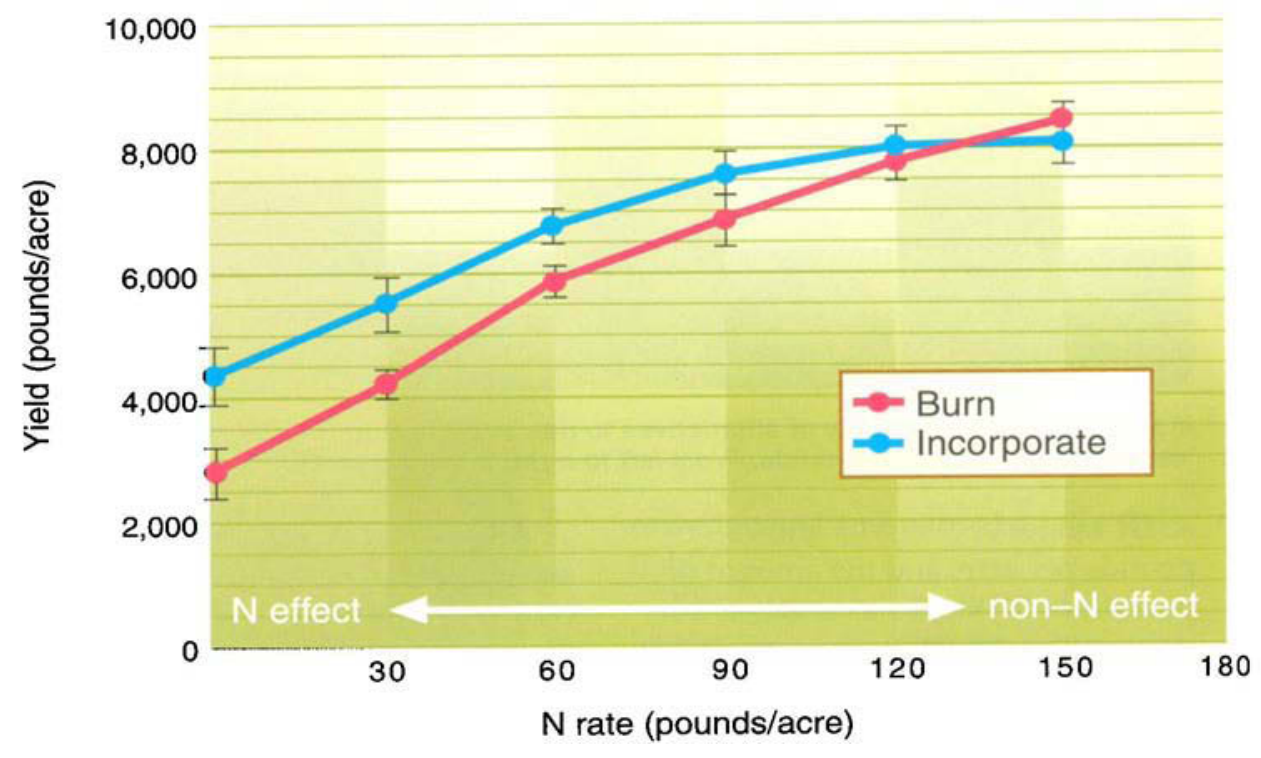

Fig. 2. Impact of burning and straw incorporation on grain yield as affected by nitrogen (N) fertilizer application in 1999. Lines in bars represent standard error.

(Bird et al. 2001)(table 2). The soil microbial biomass carbon was always significantly greater when straw was incorporated than when burned. Because soil microbial biomass is a prime source of available nitrogen for the crop, the incorporation of straw led to an increase in the crop-available soil nitrogen. Although the total soil nitrogen content had not changed after 5 years of straw incorporation or burning, a significant increase had taken place in the more labile soil nitrogen pools (that is, humic substances)(Bird et al. in press)(table 2). Those more labile soil nitrogen pools remain key sources of readily available nitrogen for crop utilization.

\section{$\mathrm{N}$ fertilizer use efficiency}

Determining the amount of nitrogen recovered by crops is reported as the nitrogen fertilizer use efficiency (FUE). Two methods of calculating FUE were compared as part of the study (Eagle et al. 2001). The first is the commonly used nitrogen-difference method. The amount of nitrogen in the crop that received nitrogen fertilizer is compared with the crop that received no nitrogen fertilizer. The difference between these two values in total nitrogen is assumed to be the amount of nitrogen from the fertilizer taken up by the crop, expressed as a percentage of the total nitrogen fertilizer applied.

A second method of determining FUE is the isotope dilution method. The total amount of nitrogen taken up by the plants is calculated using labeled nitrogen fertilizer $\left({ }^{15} \mathrm{~N}\right)$. The proportion of ${ }^{15} \mathrm{~N}$ in the crop is expressed as a percentage of the total ${ }^{15} \mathrm{~N}$ applied. A significant difference was found between the estimation of FUE using the two methods for each of the treatments (Eagle et al. 2001)(fig. 4). Although there was no significant treatment difference in FUE when calculated using either method, the large discrepancy between the two methods of estimating FUE suggests the presence of an added nitrogen interaction (ANI)(Eagle et al. 2001).

An ANI effect occurs when applied ${ }^{15} \mathrm{~N}$ is made unavailable for crop uptake by soil microorganisms. Soil microorganisms immobilize the ${ }^{15} \mathrm{~N}$-labeled nitrogen that would have been accumulated by the crop. On the other hand, through mineralization, unlabeled nitrogen becomes available, replaces fertilizer ${ }^{15} \mathrm{~N}$ in the soil solution and is accumulated by the crop. Therefore the unlabeled 


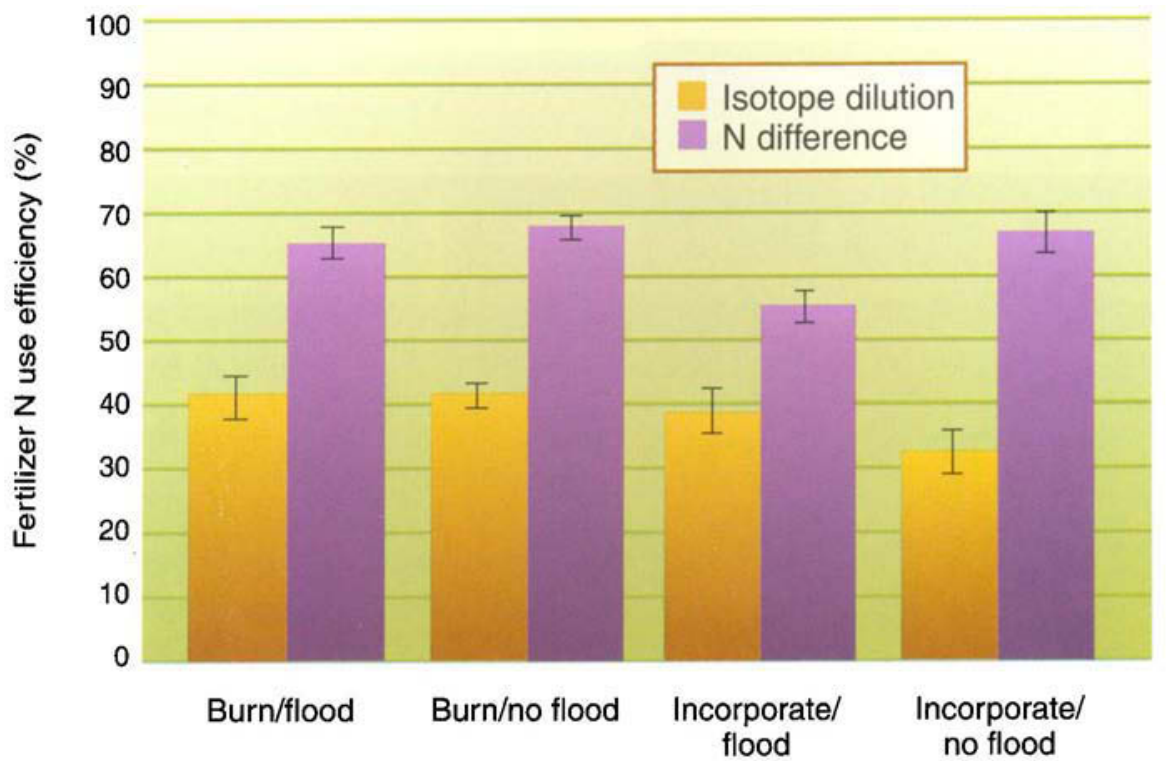

Fig. 4. Comparison of nitrogen ( $\mathrm{N}$ ) fertilizer recovery by plants using labeled fertilizer (FUE-15 $\mathrm{N}$ ) and $\mathrm{N}$ balance (FUE-ND) techniques. Lines in bars represent standard error. nitrogen previously immobilized by the soil microorganisms now becomes available for crop uptake. In other words, ${ }^{15} \mathrm{~N}$-labeled fertilizer is replaced by unlabeled nitrogen that is accumulated by the crop. This explanation is supported by the finding that the gross mineralization of nitrogen in the soil was increased significantly in the treatments where straw was incorporated (Eagle 2000). The nitrogen fertilizer recovery by the ${ }^{15} \mathrm{~N}$-isotope dilution method would have underestimated nitrogen fertilizer recovery when an ANI occurred. The actual nitrogen fertilizer recovery would then have been higher than observed by using ${ }^{15} \mathrm{~N}$ isotopes and be closer to the value for the recovery of nitrogen that was observed for the nitrogendifference method. However, it accurately describes the fate of fertilizer and shows the importance of soil nitrogen in supplying crop need.

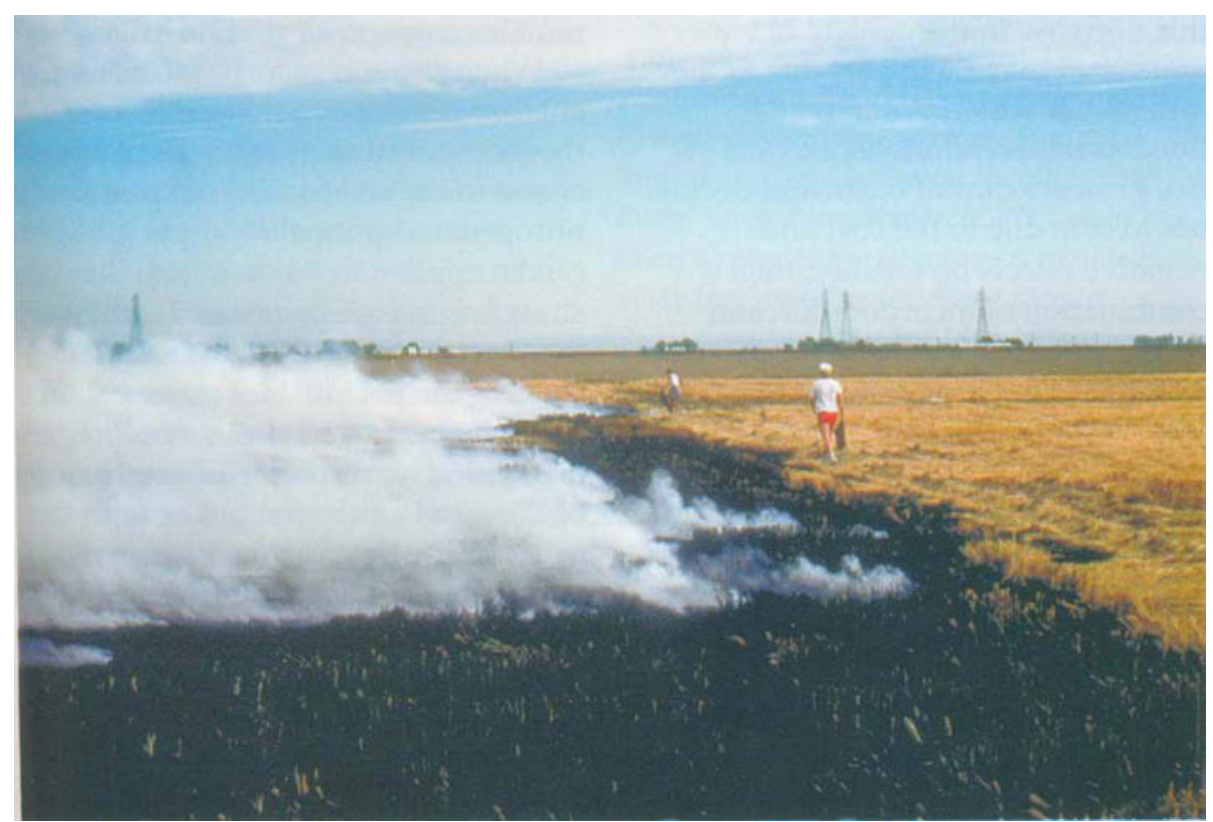

There were no major differences among various alternative practices (including burning) in terms of yield, but there was an increase in weed pressure when straw was incorporated into the soil, especially when not winter flooded.
Subsequently, we determined how much of the labeled fertilizer nitrogen was available for the following year's crop (Eagle et al. 2001). The percentage of labeled nitrogen present that was recovered in the grain of the next year's crop reached $2.9 \%$ when straw was incorporated followed by winter flooding. The recovery declined to $1.7 \%$ when the straw was burned and the field was winter flooded (Eagle et al. 2001).

Two years after the application, the total loss of nitrogen fertilizer, based on the ${ }^{15} \mathrm{~N}$ isotope balance, was approximately $50 \%$ and was largely independent of straw management practice (Bird et al. 2001). Incorporating straw did not lead to lower fertilizer nitrogen losses compared to when straw was burned. Although there were no significant differences in total soil nitrogen under the various straw management practices, there was an increase in soil microbial biomass (Bird et al. 2001) and the more available soil organic matter nitrogen pool - that is, humic nitrogen (Bird et al. in press)(table 2). An increase in total soil microbial biomass in combination with a large amount of added straw could have led to a temporary strong sink for nitrogen fertilizer. The ensuing immobilization process could have led to lower nitrogen fertilizer losses.

\section{Mixed findings on weeds}

Examining the effects of the various practices on weeds showed that straw incorporation tended to increase the prevalence of grassy weeds, particularly water grass. This effect of straw incorporation became less strong when the field was winter flooded (fig. 5). When rice fields are flooded during the winter months, they attract larger numbers of foraging waterfowl. The higher incidence of weeds in the incorporated, nonwinter-flooded fields may be due to a lower incidence of waterfowl for- 


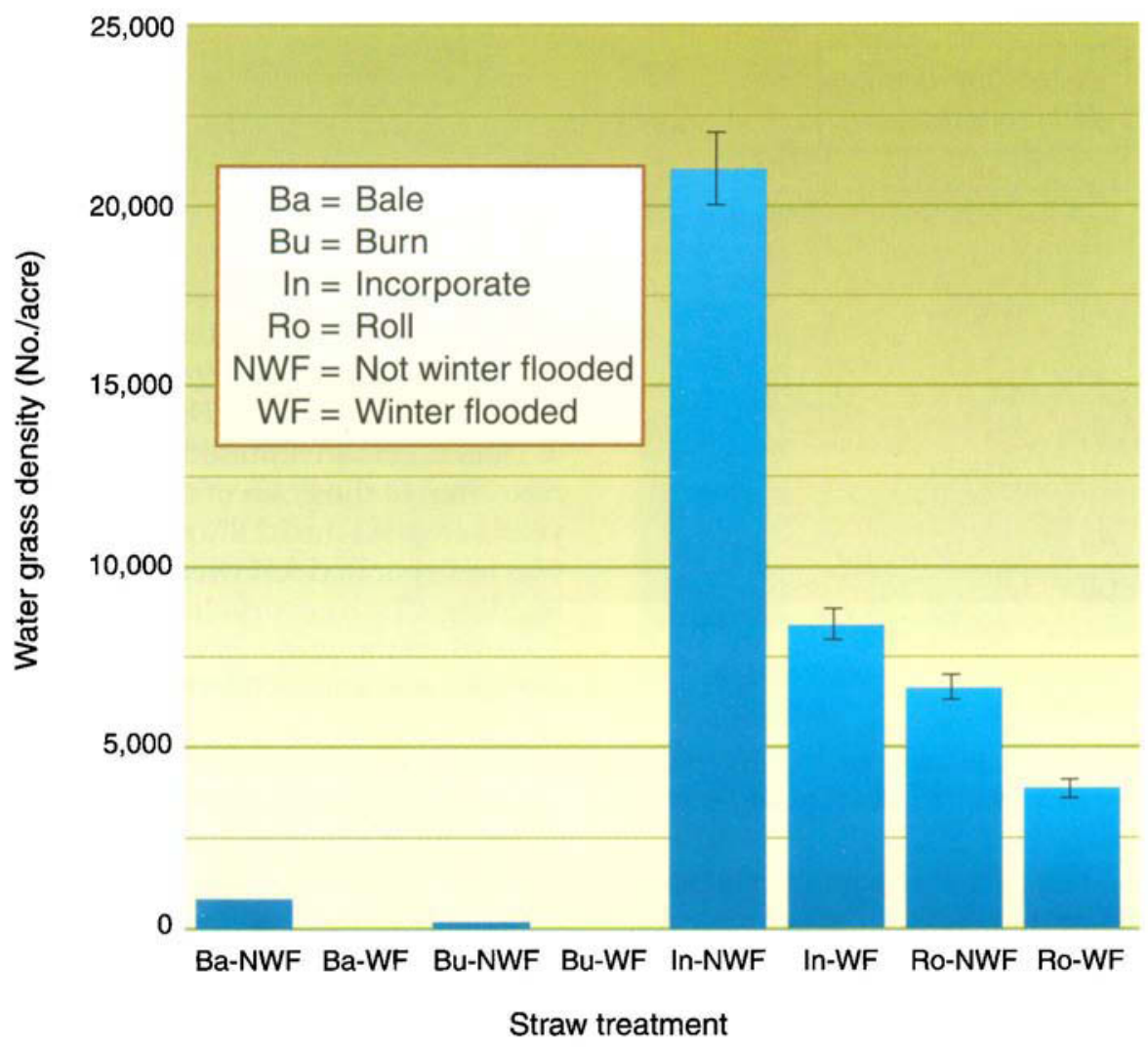

Fig. 5. Average density of mature water grass plants (Echinochloa spp.) in rice grown under different straw management practices for 7 years at Maxwell (Colusa County). Means and standard error bars are shown.

aging in these plots. Researchers found lower waterbird densities in nonflooded fallow rice fields compared with flooded in California (Elphick and Oring 1998). Winter flooding demonstrated significant benefits for weed control, whether the field was burned or not. In this study, burning and baling/removal with winter flooding produced the least water grass. Incorporation without flooding resulted in the highest amount of water grass seeds, followed by rolling without flooding. In addition, winter-flooded fields provide habitat for waterfowl, providing an example of a wildlifefriendly agronomic practice.

It is important to note that the rice fields in this study were treated with herbicides for weed control, following standard management practices. An herbicide program was used each year during this study, primarily to address the development of thiocarbamate herbicide resistance in the water grass population. For both incorporate/ winter flood and roll/winter flood, the number of water grass seeds was significantly reduced as compared to rolling or incorporating without winter flooding. The mechanism for this decrease in the density of water grass seed may be in part due to the foraging of waterfowl in winterflooded fields (unpublished data). If rice growers cannot burn, and decide not to bale due to the cost and negative effects on fertility, then a combination of incorporation and winter flooding would be an attractive alternative in terms of weed control.

\section{Environmental benefits and costs}

One question raised by researchers in this long-term study was the possibility that anaerobic decomposition in the winter-flooded fields might lead to the formation of methane, an important greenhouse gas. A research project examining methane production showed that methane was produced in all of the winter-flooded treatments, with significantly more methane pro- duced when the residue is incorporated or rolled compared to burned or baled (Bossio et al. 1999).

Over the long term, however, incorporation or rolling may also provide benefits through the accumulation of carbon as soil organic matter. To help reduce the amount of greenhouse gasses in the atmosphere, it has been suggested that producers be paid for the amount of carbon they return to the soil. Farmers would be compensated for soil carbon storage in the form of carbon credits. This policy, if implemented, could enhance farm income and offset the effects of methane production under straw incorporation.

\section{Less $\mathbf{N}$ fertilizer needed}

The various alternative rice straw management practices we tested did not lead to a decline in grain yield on our experimental plots. However, there was an increase in the weed population when straw was incorporated, in particular when the fields were not winter flooded. Increased weed pressure when straw is incorporated for a prolonged period of time remains a concern.

When straw is incorporated, nutrients are returned to the soil. Clearly, the incorporation of straw led to an increase in the soil fertility, in particular nitrogen and potassium. Less nitrogen can be applied to fields where the straw has been incorporated, resulting in reduced production costs and decreasing the potential for water pollution. When straw has been incorporated for 5 years, we recommend a reduction of 25 pounds nitrogen per acre in the rate of nitrogen fertilizer applied.

Winter flooding slightly increased rice straw decomposition in combination with straw incorporation, but decreased straw decomposition of rice crowns and stubble remaining after burning (Bird 2001). In addition, winter flooding along with waterfowl foraging at regionally observed densities 


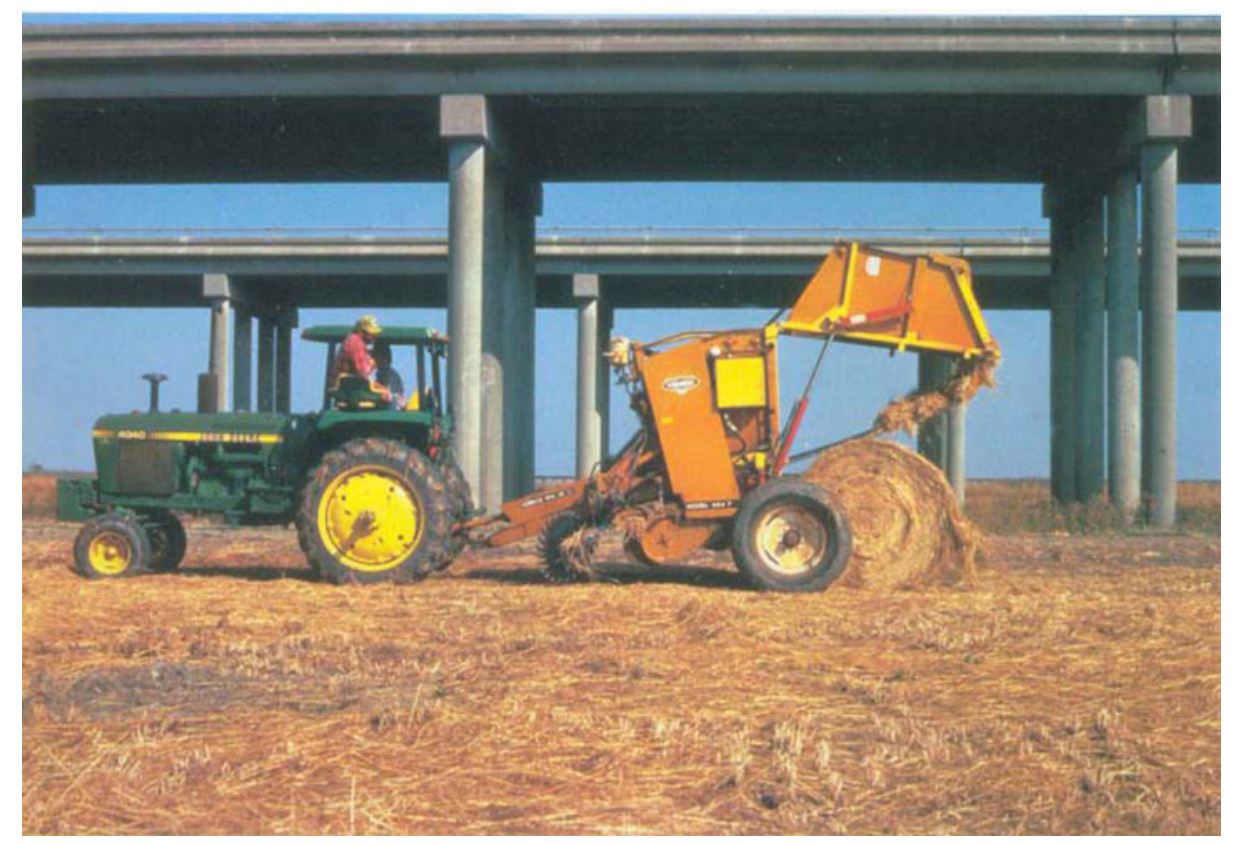

Incorporation of rice straw returned nutrients to the soil, allowing for reductions in the application of nitrogen and potassium fertilizer, without any impacts on yield. has been shown to increase straw decomposition rates in both tilled and untilled rice fields (Bird et al. 2001; unpublished data). As compared to burning, winter flooding also reduces the production of pollutants known to cause smog. Finally, ducks, geese and other birds on the Pacific Flyway benefit significantly from the wetlands that are created when fields are flooded during the winter months (Bird et al. 2000). Other studies show some benefits of winter flooding for controlling rice water weevil and the important rice disease stem rot (Hill et al. 1999).

As stated earlier, the major disadvantage to incorporation of rice straw as compared to burning is the increase in weed and possible pest pressure (Hill et al. 1999), an effect that is minimized by winter flooding. The longterm effects (more than 10 years) of straw incorporation on the occurrence and build up of weeds and pests, and how the buildup may affect the maximum yield potential for rice in California, remain to be determined. The study, which has been completed, exemplifies the need for continued longterm research because agronomic systems can take up to 10 to 20 years to respond to or equilibrate as a result of changes in residue management.
J.A. Bird is Post Doctoral Research Associate, Department of Integrative Biology, UC Berkeley; A.J. Eagle is Staff Research Associate, UC Cooperative Extension (UCCE), Kearney Agricultural Center; W.R. Horwath is Associate Professor, Department of Land, Air and Water Resources, UC Davis; M.W. Hair is Post Graduate Researcher, Department of Agronomy and Range Science, UC Davis and UCCE; E.E. Zilbert is Assistant Research Agronomist and C. van Kessel is Professor and Chair, Department of Agronomy and Range Science, UC Davis. The California Energy Commission Farm Energy Assistance Program, Ducks Unlimited and the California Rice Research Board funded this research. We would like to acknowledge the generous contributions made by Canal Farms, Steve Dennis, Steve Scardaci, Marian Llagas, Bruce Linquist, Sylvie Brouder, Jim Hill and the UC DANR Analytical Laboratory.

\section{References}

Bird JA. 2001. Soil organic matter dynamics under alternative straw management practices, Ph.D. dissertation, UC Davis. 220 p. (AAT 3007663).

Bird JA, Eagle AJ, van Kessel C, Horwath WR. 2001. Immobilization and fate of fertilizer and straw nitrogen in soil: Effects of winter flooding and straw incorporation in rice. Soil Sci Soc Am J 65:1143-52.
Bird JA, Pettygrove GS, Eadie JM. 2000 The impact of waterfowl foraging on the decomposition of rice straw: Mutual benefits for rice growers and waterfowl. J Appl Ecol 37:728-41.

Bird JA, van Kessel C, Horwath WR. In press. Nitrogen sequestration and turnover in SOM fractions under alternative straw management practices. Soil Sci Soc Am J.

Bossio DA, Horwath WR, Mutters RG, van Kessel C. 1999. Methane pool and flux dynamics in a rice field following straw incorporation. Soil Biol Biochem 31:1313-22.

[CRARB/CDFA] California Rice Air Resources Board and California Department of Food and Agriculture. 2000. Progress Report on the Phase Down of Rice Straw Burning in the Sacramento Valley Air Basin. 1999 Report to the Legislature. $38 \mathrm{p}$.

Eagle AJ. 2000. Rice yield and nitrogen dynamics as affected by alternative residue management practices and winter flooding. M.Sc. thesis, UC Davis. $91 \mathrm{p}$.

Eagle AJ, Bird JA, Hill JE, et al. 2001. Nitrogen dynamics and fertilizer nitrogen use efficiency in rice following straw incorporation and winter flooding. Agron J. 93:1346-54.

Eagle AJ, Bird JA, Horwath WR, et al. 2000. Rice yield and nitrogen utilization efficiency under alternative straw management practices. Agron J 92:1096-103.

Elphick CS, Oring LW. 1998. Winter management of California rice fields for waterbirds. J Appl Ecol 35:95-108.

Hill JE, Brandon DM, Brouder AM, et al. 1999. Agronomic implications of alternative straw management practices. In: Winter Flooding and Straw Management: Implications for Rice Production 1994-1996. Agron Progress Rep, Ag Exp Stat and Cooperative Extension, UC Davis. $116 \mathrm{p}$. 